\title{
Effect of Health Investment on Economic Growth in Nigeria
}

\author{
Akintunde Temitope S. ${ }^{1}$, Satope Bola F. ${ }^{2}$ \\ ${ }^{1}$ Dept. of Economics, College of Social and Management Sciences, Osun State University, Nigeria \\ ${ }^{2}$ Dept. of Personnel Management and International Relations, College of Social and Management Sciences, \\ Osun State University, Nigeria
}

\begin{abstract}
This study investigates the effect of health investment on economic growth in Nigeria, from 1977 to 2010. Using the vector error correction model, the study finds that there is a long run relationship between health expenditure and economic growth. The results from the study also reveal a positive relationship between health expenditure and economic growth in Nigeria. However, the results from the vector error correction model showed that in the short run, the impact of health expenditure on the economic growth did not converge to the long run growth. Investment in health could boost economic growth, if government invests more in this aspect of human capital.
\end{abstract}

Keywords: Economic Growth, Health

\section{Introduction}

Investment in health is not only desirable, but also an essential priority for most societies, both in developed and developed economies. Despite the growing body of evidence on the benefits of health investment, it has remained low in most developing countries. The proportion of health expenditure to GDP has remained well below EU average of 9- 10\% in many countries.(Atun and Gurol, 2005, [1] ). According to Scheffler (2004, [2]), the old approach has always been to develop a country first, and then spend resources on health. Health spending is something you want to postpone, something not really necessary for development. The new approach is that, if you really want to successfully develop a country economically, you have to spend a fair amount of money on healthcare in the development process. This has emphasized the importance of investing in health of a nation particularly, Nigeria.

Nigeria is faced with several health challenges and there is need to invest adequately in the health sector in order to improve the country's productivity. For instance, the HIV/AIDS prevalence rate was 3.6 in 2009 , the maternal mortality is among the highest in the world with about 840 per 10,000. The under-five mortality is also high with about 143 per 1,000 in 2010 (UNICEF, 2010,[3]). One of the main factors responsible for the poor state of Nigeria's health system is financing.

Many researchers have examined the effects government educational spending has on a country's growth and development especially in Nigeria, (Dauda2010, [4]; Adawo, 2011, [5]). However, human capital consists of two components; one is education and the other is health. It is surprising that health, which is another component of human capital, has been largely ignored in the growth studies and yet health is also a significant factor for long-run growth. In the past, much of the planning in Nigeria was centered on the accumulation of physical capital for rapid growth and development, without recognition of the important role played by human capital in the development process. There can be no significant economic growth in any country without adequate human capital development (Ogujiuba and Adeniyi 2005, [6]).

In view of the above, this study hopes to bridge the gap in the literature by investigating the effect of government investment on health on economic growth in Nigeria, from 1977 to 2010 . The study adopts the vector error correction model in order to find out both the short run and the long run relationship between health investment and economic growth in Nigeria. The study is presented as follows; relevant literature are reviewed in the next section, in the third section, models are specified and the fourth section is on the data and methodology, while in section five results are discussed and in the last section, conclusions are drawn.

\section{Theoretical and Empirical Literature}

Various theories of economic growth have tried to provide a link between health and economic growth. The neoclassical theory of growth developed by Solow and Swan attracted macroeconomists' attention throughout the 1960's and 1970's on tangible (physical) capital formation as the driver of economic growth.

However, the theory showed that, because of decreasing marginal returns in substituting physical capital for labour, the accumulation of capital would not indefinitely support a steady rate of growth in labour productivity (Barro, 1996, [7]). The recent literature on "endogenous economic growth" emerged primarily as an attempt to encompass the sources of technological progress and hence of sustained productivity growth within the general equilibrium framework of neoclassical growth theory. This literature has evolved to provide 
several distinct explanations of the process of economic growth, each of which carried particular empirical and policy implications (Ogujiuba and Adeniyi, 2005, [6]).

Subsequent endogenous growth models have fleshed out the process of technological change through the explicit introduction of human capital and/or knowledge. Lucas 1988, [8]) considers human capital to be another input in the production function. Consequently, a theoretical study carried out by Van Zon and Muysken (1997, [9]) includes health into the Lucas's (1988, [8]) endogenous growth framework. In their model, healthy labour is not only used in the production of goods and knowledge but it is also necessary to maintain health. As a consequence the characteristics of the health sector have a clear impact on economic growth and optimal health expenditures were analysed. Muysken et al. (2005, [10]) introduced health in a standard Ramsey-type growth model. In that context they developed an alternative measure of health status of an economy; the ratio of man-hours effectively supplied (and employed) to the total amount of man-hours available. The model showed a positive contribution of good health to steady state output (and economic growth) for an exogenous health status.

Some studies on health and economic growth found a positive relationship between the two. For instance, Leu (1986, [11]), Parkin et. al. (1987, [12]), Pritchett and Summers (1996, [13]) and Barros (1998, [14]) studied the impact of income on health at the macro level. They found a strong effect of income in explaining health experiences. Barro (1991, [15]) and Barro and Sala-i-Martin (1992, [16]),( Knowles and Owen, 1995, [17] and 1997, [18]) have investigated the positive effect of health on economic development.

They also found a strong effect of health in explaining income per capita differences. Ogundipe and Lawal (2011, [19]) examined the impact of health expenditure on economic growth in Nigeria. Using the OLS technique, they found a negative effect of total health expenditure on growth. This present study differs from their (Ogundipe and Lawal, [19]) study, first, this study covers more period (i.e. 1977-2010) and the study made use of the vector error correction model in order to ensure that the estimates are efficient and consistent. In addition, Mehrara and Musai $(2011,[20])$ investigated the relationship between health expenditure and economic growth in Iran from 1970 to 2007. Using the autoregressive distributed lag approach, they found a negative impact of health expenditure on output both in the short and long run. In the same vein, Bukenya (2009, [21]), found a positive but weak relationship between health expenditure and economic growth in some states in the United States.

\section{Model Specification}

This study made use of the endogenous growth model. The theoretical model followed that of Ericsson and Irandoust (2001, [22]). Starting from the Cobb Douglas production function we have;

$\mathrm{Y}=\mathrm{A} \mathrm{K} \mathrm{K}^{\alpha} \mathrm{L}^{\beta}$

Where; $Y=$ output

$\mathrm{A}=$ efficiency, it captures the variable influencing the level of productivity in the economy. It contains control and policy variables as well as technology.

$\mathrm{K}=$ Capital; $\mathrm{L}=$ Labour force

Following the endogenous growth literature, $\mathrm{K}$ is decomposed into physical capital, $\mathrm{K}_{\mathrm{P}}$, and human capital, $\mathrm{K}_{\mathrm{H}}$, that is;

$\mathrm{K}=\left[\mathrm{K}_{\mathrm{p}}{ }^{\theta}, \mathrm{K}_{\mathrm{H}}{ }^{\delta}\right]$

Where $\theta+\delta=\alpha$

Thus substituting equation (1) into (2) becomes;

$\mathrm{Y}=\mathrm{A}\left(\mathrm{K}_{\mathrm{p}}{ }^{\theta}, \mathrm{K}_{\mathrm{H}}{ }^{\delta}, \mathrm{L}^{\beta}\right)$

Dividing both sides by $\mathrm{L}^{\beta}$ becomes;

$\mathrm{Y} / \mathrm{L}^{\beta}=\mathrm{A}\left(\mathrm{K}_{\mathrm{p}}^{\theta} / \mathrm{L}^{\beta}, \mathrm{K}_{\mathrm{H}}{ }^{\delta} / \mathrm{L}^{\beta}\right)$

$(\mathrm{Y} / \mathrm{L})^{1-\beta}=\mathrm{A}\left[\left(\mathrm{K}_{\mathrm{P}} / \mathrm{L}\right)^{\theta-\beta}\left(\mathrm{K}_{\mathrm{H}} / \mathrm{L}\right)^{\delta-\beta}\right]$

Rewrite equation (5)

$(\mathrm{y})^{1-\beta}=\mathrm{A}\left[\left(\mathrm{k}_{\mathrm{P}}\right)^{\theta-\beta}\left(\mathrm{k}_{\mathrm{H}}\right)^{\delta-\beta}\right]$

Where

$\mathrm{y}=\mathrm{Y} / \mathrm{L} ; \mathrm{k}_{\mathrm{P}}=\mathrm{K}_{\mathrm{P}} / \mathrm{L} ; \mathrm{k}_{\mathrm{H}}=\mathrm{K}_{\mathrm{H}} / \mathrm{L}$

Make $y$ the subject of formula yields;

$\mathrm{y}=\mathrm{A}\left[\left(\mathrm{k}_{\mathrm{P}}\right)^{\theta-\beta}\left(\mathrm{k}_{\mathrm{H}}\right)^{\delta-\beta}\right]^{1 / 1-\beta}$

By taking the logarithm of equation (7), we have a general equation of the form;

$\ln y=\ln A+[\theta-\beta / 1-\beta] \ln k_{p}+[\delta-\beta / 1-\beta] \ln k_{H} \ldots$

In endogenous growth models, however, technology (A), the ultimate cause of growth evolves endogenously. It is not the consequence of a deliberate action by any economic agent. The models of Aghion and Howitt (1992, [23]), Romer (1990, [24]) associated evolution of technology with a measureable input such as research and development expenditure, the number of engineers, etc. The level of technology, which is fundamental to the endogenous growth model, is assumed to be of the form: 
$\ln \mathrm{A}=\ln \mathrm{A}_{0}+\lambda(\mathrm{z})$

where $\mathrm{z}$ is a set of other economic and non-economic policy variables that affects growth. Given equation (9), the equation becomes

$\ln y=\ln A_{0}+\lambda(z)+[\theta-\beta / 1-\beta] \ln k_{p}+[\delta-\beta / 1-\beta] \ln k_{H}$

where $\ln \mathrm{A}_{0}$ is assumed to be constant and $\mathrm{z}$ is the degree of openness.

Therefore, we have;

$\ln \mathrm{y}=\ln \mathrm{A}_{0}+\lambda(\mathrm{dop})+[\theta-\beta / 1-\beta] \ln \mathrm{k}_{\mathrm{p}}+[\delta-\beta / 1-\beta] \ln \mathrm{k}_{\mathrm{H}}$

Openness to trade increases the incentives to invest in research and development by widening the extent of the markets. One result from this extension is that the opening up of the economy to the world credit markets speeds up the predicted rate of convergence to the steady state. A country with more human capital would be more adept at the adaptation of technologies that were discovered elsewhere. Thus, the higher the stock of human capital for a follower country, the higher the rate of absorption of the leading technology and hence, the higher the follower country's growth rate. Therefore, increased openness to trade makes capital mobility feasible for adaptation. (Olomola, 2003, [25]).

For empirical purposes, we write the equation as:

$\ln \mathrm{y}=\lambda_{0}+\lambda_{1} \ln \operatorname{dop}+\lambda_{2} \ln \mathrm{k}_{\mathrm{p}}+\lambda_{3} \ln \mathrm{k}_{\mathrm{H}}+\varepsilon_{\mathrm{t}}$

where $: \lambda_{0}=$ constant term; $\lambda_{2}=[\theta-\beta / 1-\beta] ; \lambda_{3}=[\delta-\beta / 1-\beta] ; \varepsilon_{\mathrm{t}}=$ error term

Equation 12 was estimated using regression method

Where

$\mathrm{k}_{\mathrm{H}}$ - is health investment proxied by the ratio of government spending on health to the labour force. Its coefficient is expected to be positive.

$\mathrm{k}_{\mathrm{p}}$ - is private investment, proxied by the ratio of gross capital formation to the labour force. As an increase in the investment ratio captures an increase in the stock of physical capital its coefficient is expected to be positive.

$\mathrm{y}$ - is per capita income dop- is the degree of openness measured in terms of the ratio of import plus export to GDP. Its coefficient is expected to be positive.

$\ln \mathrm{y}$ is the dependent variable while the remaining three variables are the explanatory variables.

\section{Data and Methodology}

The study made use of secondary data. Empirical investigation was carried out on the basis of the sample period covering 1977 to 2010. Data were obtained from the following: Statistical Bulletin of the Central Bank of Nigeria of various editions; and International Financial Statistics published by the International monetary Fund of various years;

To examine the impact of health investment on the economic growth, the real variables were used. The first step was to examine the time series properties of the variables under consideration using the Augmented Dickey Fuller (ADF) tests. Next was to determine the long run relationship among the variables using the Johansen Co integration procedure (Johansen 1991, [26] and Johansen and Julius 1990, [27]). Lastly, the procedure involves the estimation of Vector Error Correction (VECM) in order to obtain the likelihood -ratios (LR) for the short-run relationship

Central to this framework of analysis is the examination of the variable in the econometric model for stationarity. This is to ascertain the order of integration of the variables and the number of time the variables have to be differenced to arrive at stationarity. This enables us to avoid the problems of spurious or inconsistent regressions that are associated with non-stationary time series models.

The Augmented Dickey- Fuller (ADF) tests is specified as;

$\Delta \mathrm{Y}_{\mathrm{t}}=\alpha+\beta \mathrm{Y}_{\mathrm{t}-1}+\sum_{\mathrm{j}=1} \Delta \mathrm{Y}_{\mathrm{t}-1}+\varepsilon_{\mathrm{t}}$

Where $\Delta$ is the difference operator

$\mathrm{Y}$ represents the vector of variables considered in this study namely lyr (output), lkpr (private investment), $1 \mathrm{khr}$ (health investment), and ldopr (degree of openness).

$\beta$ is negative and significantly different from zero, then the series is $\mathrm{I}(0)$ that is, stationarity.

$\varepsilon_{t}$ is the error term which should be a white noise. The t statistics computed in equation (13) for the coefficient $\beta$ is the ADF test.

Co integration test was carried out using Johansen co integrating procedure (Johansen 1991, [26] and Johansen and Juselius 1990, [27] ). The equation is specified as;

$\Delta \mathrm{Y}=\prod \mathrm{Y}_{\mathrm{t}-1}+\sum \Gamma \Delta \mathrm{Y}_{\mathrm{t}-1}+\mu+\mathrm{v}_{\mathrm{t}}$

Where $\mathrm{Y}=$ (lyr, lkpr, lkhr, ldopr)

$\Delta$ is the difference operator that induces stationary, $\mu$ is the intercept or constant and $v_{t}$ is a vector normally and independently distributed error terms, $v=\left(v_{1 t}, v_{2 t}\right)$. The model is assumed to be vector white noise, that is, $\mathrm{v}_{\mathrm{t}}$ has mean zero. 
$\mathrm{E}\left[\mathrm{v}_{\mathrm{t}}\right]=0$, and nonsingular covariance matrix $\sum_{\mathrm{v}}=\mathrm{E}\left[\mathrm{v}_{\mathrm{t}} \mathrm{v}_{\mathrm{t}}\right]$ for all. The coefficient matrix $\prod$, is also referred to as the long run impact matrix, contains information about the stationarity of the variables and the long run relationship between them. The existence of co integrating vectors (v) implies $\prod$ is rank-deficient (Kul and Khan, 1999, [28]). If $\prod$ is of full rank, that is, $r=p$, then all variables in $Y$ are themselves stationary with no common stochastic trend or long run relationship exists between them. On the other hand, if $\prod$ is a full matrix, that is, $\mathrm{r}=0$, then co integrating is not also present but variables in $\mathrm{Y}$ are non-stationary. The number of significant non-zero eigen value determines the number of co integrating vectors in the system. However, if $\prod$ is of rank $r(0<r<p)$, then there are $r$ linear combinations of variables in that are stationary. This indicates that the variables are co integrated in the long run with $r$ co integrating vectors.

After co integration, a vector error correction model was used to explore the effects of short-term variation and deviation from the co integrating relationship on the variables. It is based on the regression equation; $\Delta \mathrm{Y}_{\mathrm{t}}=\mu+\sum \Gamma \Delta \mathrm{Y}_{\mathrm{t}-1}+\alpha E C_{\mathrm{t}-1}+\varepsilon_{\mathrm{t}}$

Where $\mathrm{EC}_{t}$ is the error correction term given by $\beta^{\prime} \mathrm{Y}_{\mathrm{t}}$ and $\beta$ is the co integrating vector. The $\alpha$ coefficient vector reveals the speed of adjustment to the deviation from the long run relationship between the variables.

\section{Results}

As a first step, the time series properties of each of the variables in the model have to be tested for stationarity. The aim was to determine the order of differencing to achieve stationarity. The Augmented Dickey Fuller (ADF) test was used to check for stationarity of the variables.

\subsection{Unit Root Test}

Table 1: ADF Unit Root Test (Without Trend)

\begin{tabular}{|l|l|l|}
\hline Series & Levels & First Difference \\
\hline Lyr & -2.02 & -4.15 \\
\hline Lkpr & -2.11 & -4.32 \\
\hline Lkhr & -1.55 & -4.61 \\
\hline L(dopr) & -0.60 & -3.72 \\
\hline
\end{tabular}

Source: Author's Computation

The results of the ADF unit root tests are presented in Table 1 and the test was without trend. For all the variables, the null hypothesis was rejected at levels with one lag. This means that the variables were nonstationary that is, they were not I(0) series at levels. After first differencing, the variables of no unit root were rejected for all the variables. This means that after first difference, the variables were non-stationary that is, they were of I(1) series at 5\% significant level. The next step was to test for co integration using the Johansen co integration test. The results were presented in the table below.

\subsection{Johansen Co integration Test}

The study applied the multivariate co integration technique developed by Johansen (1991, [26]) to the system of four variables, which were integrated of order one, to investigate the existence or otherwise of long run linkages among the variables.

Table 2: Co integration Test

\begin{tabular}{|c|c|c|c|c|}
\hline \multicolumn{5}{|c|}{ Table 2: Co integration Test } \\
\hline Eigenvalue & $\begin{array}{l}\text { Likelihood } \\
\text { Ratio } \\
\end{array}$ & $\begin{array}{l}5 \text { Percent } \\
\text { Critical Value }\end{array}$ & $\begin{array}{l}1 \text { Percent } \\
\text { Critical Value }\end{array}$ & $\begin{array}{l}\text { Hypothesized } \\
\text { No. of CE(s) }\end{array}$ \\
\hline 0.885011 & 72.19167 & 47.21 & 54.46 & None $* *$ \\
\hline 0.360732 & 20.28162 & 29.68 & 35.65 & At most 1 \\
\hline 0.255310 & 9.543253 & 15.41 & 20.04 & At most 2 \\
\hline 0.097736 & 2.468349 & 3.76 & 6.65 & At most 3 \\
\hline
\end{tabular}

L.R. test indicates 1 co integrating equation(s) at 5\% significance level Source: Author's Computation From table 2, the null hypothesis of no co integration was also rejected for the real variables. This was because there was at least one co integrating vectors but at the interval of 1 to 2 lags. It indicated that the variables also had long-run relationship and a vector error correction model can be specified as well. Rearranging the normalized co integrating equation, the result was given as;

Lyr $=2.74+0.361 \mathrm{kpr}+0.041 \mathrm{kHr}-0.031 \mathrm{dopr}$

$\mathrm{t}=\quad(31.86)$ 
Table 3: Long-run Effects of Health Investment on Economic Growth

\begin{tabular}{|l|l|}
\hline Explanatory variables & Coefficients \\
\hline Health Investment & $0.04(4.56)$ \\
\hline Private Investment & $0.36(31.86)$ \\
\hline Degree of Openness & $-0.03(-6.92)$ \\
\hline
\end{tabular}

Note that the $\mathrm{t}$ statistics are in parentheses

Source: Author's Computation

The long-run effect of health investment on growth is found in table 3. The long run effect was obtained through the normalization of the co integrating equation. All the variables were significant because the t-ratios were significant at 5\% significance level. The result revealed that the private investment and health investment had a positive sign but the degree of openness had a negative sign. The health investment had a positive sign by implication, a $1 \%$ increase in health investment caused about $0.04 \%$ increase in the real output.

The increased government spending on health could accelerate economic growth, this gives the impression that in Nigeria over the years, government outlay on health(recurrent and capital) tend to be growth promoting. The positive relationship between health investment and real output could be due to the fact that the Nigerian government have over the years spend money in constructing hospitals, dispensaries, wards, training of medical personnel, importation of drugs and encouragement of local pharmaceutical companies. There had been significant progress in medical technology, public health services and education which allowed Nigeria to realize "more health" for a given income than before (Soubbotina 2004, [29]). This finding conforms with studies by Mehrara and Musai (2011, [20]), however, it contrasts studies by Ogundipe and Lawal (2011, [19]).

The private investment had positive impact on the output. This showed that private investment can spur growth in Nigeria. Private investment was positively correlated with economic growth, over the years, private investment in the country had been on the increase and this may be as a result of increasing inflow of foreign private investment which may be due to the fact that the cost of operation is comparatively low in Nigeria and increasing domestic private investment in the country. Also, the privatization of many public infrastructures had helped in boosting private investment in the county. The degree of openness had negative influence on the output. The result did not conform to the a-priori expectation but it is similar to the findings by Edwards (1989, $[30])$.

\subsection{Vector Error Correction Model}

The VECM allows the long-run behaviour of the endogenous variables to converge to their co integrating, that is, long-run equilibrium relationships while allowing a wide range of short-run dynamics.

Table 4: Short run Effects of Health Investment on Economic Growth

Note that the $t$ statistics are in parentheses.

\begin{tabular}{|l|l|l|}
\hline Variables & Lagged Co integrated Equation & $\mathrm{R}^{2}$ \\
\hline Real (LYR) & $14.18(3.09)$ & 0.64 \\
\hline
\end{tabular}

Source: Author's Computation

The short run effects of health expenditure on economic growth were analyzed using the coefficient from the lagged VECM. We adopted the variance decomposition and the impulse response to calculate the impacts of the variables as they interact with one another over a given time horizon. From table 4, the coefficient on the lagged VECM for the variables was 14.18 . They were significant at 5\%. These contrasted sharply with a-priori expectation since the lagged VECM was supposed to be negative and significant. By these results, the short run effect of health spending on economic growth deviated far from the long run effect. The implication was that the short run impact of health spending on growth may be low although significant. This can further be established by examining the variance decomposition and the impulse response. Evidence from the table above showed that the $\mathrm{R}^{2}$ was about $64 \%$.

\subsection{Variance Decomposition}

Variance decomposition measures the percentage of variation in the endogenous variables induced by the shocks (innovations) emanating from any of the variables in the system. The ordering of the variables used for this study followed from the degree of openness to private investment to health investment and to output growth. (LDOPR - LKPR - LKHR - LYR). The reason for this ordering is that technology transfer occurs in Nigeria. Foreign technologies are imported to complement the existing domestic technology. Much of these technologies are then used for private investment. For instance, much of the machines used for mechanized farming come from abroad, machines and equipment used in the manufacturing sector, power sector and even oil and gas come from these foreign countries. Also, experts come from these foreign countries to manage some of these machines. Still following the ordering mentioned above, this then influence the health sector because 
hospitals rely heavily on equipment from abroad e.g. scanning machine, dialysis machine to mention a few. All these then have impact on the economic growth in Nigeria.

We decomposed the forecast error variance in the model, using Choleski decomposition method, in order to identify the most effective instrument to use in targeting each variable of interest. We used the VEC model to decompose the innovations of the endogenous variables into portions that can be attributed to their own innovations and to innovations from other variables. The impacts on output growth and health investment of innovations in other variables were reported here.

The real output (LYR) accounted for only about 7\% in the first year of the 10 -year forecast error variance on itself. In the second year it rose considerably to about $25 \%$ and it tried to stabilize around $25 \%$ till the tenth period. In the first year, the real private investment was a predominant source of variation in real output with about $75 \%$ but in the following year it declined to about $30 \%$. In the fourth year it rose a little to about $35.4 \%$ and it then declined gradually and set to stabilize at $31 \%$ from the eighth period. Shocks from real health investment were also important source of the forecast error variance in real output. Though in the first year real health investment's contribution to real output was $14 \%$ but in the second year it rose considerably to about $43 \%$, declined to about $37 \%$ in the fourth period. In the sixth period, it rose to about $43 \%$ again and in the tenth year it was $41 \%$. The real degree of openness accounted for about $4 \%$ of the forecast error variance in real output in the first period and it gradually declined to about $1 \%$ in the tenth year. The contribution of the real private investment to the real output was an average of $36 \%$ while that of real health investment and real degree of openness were $39 \%$ and $2 \%$ respectively.

This result indicated that both health investment and private investment contributed significantly to the economic growth in Nigeria while the degree of openness was not contributing much to the country's growth process. This was also similar to the findings from the normalized cointegrated equation.

Table 5: Variance Decomposition of LYR

\begin{tabular}{|l|l|l|l|l|l|}
\hline PERIOD & S.E. & LYR & LKPR & LKHR & LDOPR \\
\hline 1 & 0.09 & 6.91 & 74.60 & 14.03 & 4.46 \\
\hline 2 & 0.36 & 25.26 & 29.98 & 43.32 & 1.45 \\
\hline 3 & 0.41 & 24.88 & 31.71 & 42.20 & 1.21 \\
\hline 4 & 0.44 & 26.71 & 35.35 & 36.90 & 1.03 \\
\hline 5 & 0.45 & 25.71 & 34.91 & 37.39 & 1.99 \\
\hline 6 & 0.48 & 24.98 & 30.28 & 42.78 & 1.96 \\
\hline 7 & 0.48 & 24.97 & 30.24 & 42.73 & 2.06 \\
\hline 8 & 0.50 & 24.31 & 30.96 & 42.70 & 2.03 \\
\hline 9 & 0.62 & 25.45 & 30.83 & 42.31 & 1.40 \\
\hline 10 & 0.67 & 26.09 & 31.30 & 41.40 & 1.21 \\
\hline
\end{tabular}

Source: Author's Computation

The major source of variation in real health investment's forecast error was its own shocks which accounted for between $78 \%$ and $64 \%$ over a ten-year period. Shocks from real output were not significant in the first year but in the second year, it contributed about $6 \%$ to the real health investment. It rose to about $16 \%$ in the fifth period and later declined a little bit. At the tenth period it was $15 \%$. Innovations from the real private investment were not significant in the first year but in the second year it rose to about $12 \%$. From the ninth period it sets to stabilize with about $14 \%$. Shocks from the real degree of openness accounted for about $22 \%$ in the forecast error variance in real health investment in the first year and it gradually declined to about $6 \%$ from the fifth period and it tried to stabilize with that throughout the remaining period.

Table 6: Variance Decomposition of LKHR

\begin{tabular}{|l|l|l|l|l|l|}
\hline PERIOD & S.E. & LYR & LKPR & LKHR & LDOPR \\
\hline 1 & 0.24 & 0.00 & 0.00 & 77.95 & 22.05 \\
\hline 2 & 0.46 & 6.14 & 11.83 & 70.88 & 11.145 \\
\hline 3 & 0.78 & 15.37 & 10.84 & 68.29 & 5.51 \\
\hline 4 & 0.90 & 14.73 & 12.29 & 67.85 & 5.13 \\
\hline 5 & 1.02 & 16.07 & 13.57 & 64.50 & 5.86 \\
\hline 6 & 1.03 & 16.17 & 14.34 & 63.39 & 6.10 \\
\hline 7 & 1.03 & 16.39 & 14.30 & 62.87 & 6.44 \\
\hline 8 & 1.08 & 15.34 & 13.19 & 65.25 & 6.21 \\
\hline 9 & 1.16 & 14.00 & 13.72 & 65.62 & 6.66 \\
\hline 10 & 1.42 & 15.48 & 14.36 & 64.21 & 5.95 \\
\hline
\end{tabular}

Source: Author's Computation

\subsection{Impulse Response}

Since the variance decomposition only estimates the proportions of the variance but cannot indicate whether the impact is positive or negative, or whether it is a temporary jump or long run persistence, impulse 
response functions are estimated to give the indication of the system's dynamic behaviour as it traces the response of the endogenous variables to a shock in another variable in the system. The ordering still followed the one earlier mentioned. The impulse response was presented in the tables below. For the purpose of this study, interest was only on the response of output and the response of the investment on health (LYR and LKHR). The impulse response functions were implemented with a ten-year horizon. Impulse response functions give an indication of the lag structure in the economy.

A positive shock on real output yielded a response of about $0.02 \%$ in the first year. In the second year it rose to $0.1 \%$ but in the fifth year it declined to $-0.01 \%$, it rose again to about $0.01 \%$ in the seventh period and at the tenth period it was $0.1 \%$. A $1 \%$ standard deviation innovation on the real private investment yielded about $0.08 \%$ response on the real output in the first year. It rose a little bit up till the fourth year maintaining a temporary shock but from the fifth year it declined to $-0.04 \%$ later it rose again and at the tenth period it was about $0.2 \%$. A positive shock on the real health investment brought about a positive response on the real output from the first year to the fourth year then, it brought a negative response in the fifth and sixth period and later it became positive again with about $0.2 \%$ at the tenth period. A positive shock on the real degree of openness caused a positive response in the first year. Then in the second and third year, decayed to become negative and then rose gradually again and later declined to become negative again. The response from the degree of openness was not stable at all.

Table 7: Response of LYR

\begin{tabular}{|l|l|l|l|l|}
\hline Period & LYR & LKPR & LKHR & LDOPR \\
\hline 1 & 0.02 & 0.08 & 0.03 & 0.02 \\
\hline 2 & 0.18 & 0.18 & 0.23 & -0.04 \\
\hline 3 & 0.09 & 0.12 & 0.12 & -0.01 \\
\hline 4 & 0.10 & 0.13 & 0.04 & 0.00 \\
\hline 5 & -0.01 & -0.04 & -0.06 & 0.04 \\
\hline 6 & -0.10 & -0.02 & -0.16 & 0.02 \\
\hline 7 & 0.01 & -0.01 & 0.01 & 0.02 \\
\hline 8 & 0.03 & 0.07 & 0.07 & 0.01 \\
\hline 9 & 0.20 & 0.21 & 0.24 & -0.02 \\
\hline 10 & 0.14 & 0.15 & 0.15 & -0.01 \\
\hline
\end{tabular}

Source: Author's Computation

A positive shock on the real output yielded no response on the real health investment in the first year but in the second year it rose to about $0.11 \%$. In the sixth period it became negative and it rose again from the $8^{\text {th }}$ period with about $0.07 \%$ and at the $10^{\text {th }}$ period, it became 0.35 . A $1 \%$ shock on the real private investment yielded a no response on the real health investment in the first year but rose in the following year to about $0.16 \%$ later it declined again to become

$-0.1 \%$ in the $6^{\text {th }}$ year. It rose again in the $9^{\text {th }}$ year and at the $10^{\text {th }}$ year it became $0.33 \%$.

A positive shock on real health investment yielded a positive response on itself all through the 10 -year horizon with $0.2 \%$ in the $1^{\text {st }}$ year and $0.6 \%$ in the $10^{\text {th }}$ year. A positive shock on the real degree of openness brought about a negative response all through the ten years on the real health investment with $-0.11 \%$ in the $1^{\text {st }}$ period and at the $10^{\text {th }}$ period it declined to $-0.18 \%$. The shock brought a permanent negative response on the real health investment.

Table 8: Response of LKHR

\begin{tabular}{|l|l|l|l|l|}
\hline Period & LYR & LKPR & LKHR & LDOPR \\
\hline 1 & 0.00 & 0.00 & 0.21 & -0.11 \\
\hline 2 & 0.11 & 0.16 & 0.32 & -0.11 \\
\hline 3 & 0.28 & 0.20 & 0.52 & -0.10 \\
\hline 4 & 0.16 & 0.19 & 0.37 & -0.09 \\
\hline 5 & 0.21 & 0.20 & 0.34 & -0.14 \\
\hline 6 & -0.07 & -0.10 & 0.04 & -0.06 \\
\hline 7 & -0.06 & -0.03 & 0.03 & -0.06 \\
\hline 8 & 0.07 & -0.04 & 0.30 & -0.06 \\
\hline 9 & 0.09 & 0.17 & 0.34 & -0.13 \\
\hline 10 & 0.35 & 0.33 & 0.65 & -0.18 \\
\hline
\end{tabular}

Source: Author's Computation

Table 7 reveals that innovations from the real private investment had greater influence on the real output in the first year though it declined later but it rose again. In Nigeria, over the years much investment had gone into infrastructures which had attracted investors to invest, and which in turn had increased private investment in the country. This supported earlier findings that private investment can spur economic growth 
(Jones 1995, [31] and Mankiw et al 1992, [32]). The shocks from the real health investment also had impact on the real output this indicated that health investment too is relevant in determining the real output.

On the other hand, from table 8 , shocks from the real private investment did not have much impact on the real health investment the response was not even stable. In Nigeria private participation in the health sector had not really been accounted for over the years. The standard deviation shocks from the real degree of openness was negative this was similar to the result from the variance decomposition where the contribution of the real degree of openness to the real health investment was small and declining.

\section{Conclusion}

The study examined the effect of health investment on economic growth in Nigeria from 1977 and 2010. The vector error correction model was employed because a long run relsationship between health expenditure and economic growth was established through the use of co integration test. The long run effect of health investment on economic growth was positive and the result from the variance decomposition and impulse response confirmed this. However, the short run effect deviated from the long run growth. This implies that investing in health could spur growth in the long run in Nigeria. Nevertheless, the issue that remains is to ensure that the amount of government spending on health is increased and used effectively for the development of the country.

\section{References}

[1]. Atun, R.and Gurol-Urganci, I., 2005. Health Expenditure: An Investment Rather Than A Cost? International Economics Programme, Working Paper 05/01.

[2]. Scheffler, R. M., 2004. Health Expenditure and Economic Growth: An International Perspective. Occasional Papers on Globalization, no. $10 \mathrm{pp}, 4-10$.

[3]. UNICEF, 2010 At a Glance: Niger available at http://www.unicef.org/infobycountry/niger_statistics.html. Assessed on 2nd February, 2011.

[4]. Dauda, R. O. 2010, Investment in Education and Economic Growth in Nigeria; An Empirical Evidence. International Research Journal of Finance and Economics. Vol. 55 pg 158-169.

[5]. Adawo, M. A., 2011. Has Education (Human Capital) Contributed to the Economic Growth of Nigeria? Journal of Economics and International Finance. Vol. 3(1), pp 46-58.

[6]. Ogujiuba, K. K. and Adeniyi, A. O., 2005. Economic Growth and Human Capital Development : The Case of Nigeria. Macroeconomics 0508023, EconWPA.

[7]. Barro, R. J., 1996. Three Models of Health and Economic Growth. Unpublished Manuscript. Cambridge, MA: Harvard University .

[8]. Lucas, R., 1988. On the Mechanics of Economic Development Journal of Monetary Economics, Vol. 22 (July), pp, 3-42.

[9]. Van Zon, A. H. and Muysken, J. (1997), "Health, Education and Endogenous Growth", MERIT, Working Paper No. 2/97-009, Maastricht, The Netherlands.

[10]. Muysken, J., Yetkiner, I. H. and Zeisemer, T., 2005. Health Labour Produtivity and Growth. University of Maastricht, Maastri cht, The Netherlands.

[11]. 11. Leu, R., 1986. The Public-Private Mix and International Health Care Cost, in Public and Private Health Services: Complementaries and Conflicts, Culyer A.J. and Jonsson, B. (eds.), Basil Blackwell: Oxford.

[12]. Parkin, D., McGuire, A., and Yule, B., 1987. Aggregate Health Care Expenditures and National Income: Is Health Care a Luxury Good? Journal of Health Economics, 6, pp, 109-27.

[13]. Pritchett, L. and Summers, L.H., 1996. Wealthier is Healthier, Journal of Human Resources, 31, pp, $841-68$.

[14]. Barros, P.P., 1998. The Black Box of Health Care Expenditure Determinants, Health Economics, 7, pp,

[15]. Barro, R., 1991. Economic Growth in a Cross Section of Countries. Quarterly Journal of Economics. Vol 106, pp, 407-443.

[16]. Barro, Robert J. and Sala-i-Martin, X., 1992 Convergence, Journal of Political Economy, No. 100, pp, 223-251.

[17]. Knowles, S. and Owen, D. P., 1995. Health Capital and Cross-country Variation in per Capita in the Mankiw-Romer-Weil Model, Economics Letters, Vol. 48 (223), pp, 99-106.

[18]. Knowles, S., and Owen, D. P., 1997. Education and Health in an Effective-Labour Empirical Growth Model. Economic Record 73(223), pp, 314-328.

[19]. Ogundipe, M.A. and Lawal, N.A., 2011. Health Expenditure and Nigerian Economic Growth. European Journal of Economics, Finance and Administrative Sciences, Issue 30.

[20]. Mehrara, M. and Musai, M., 2011. Health Expenditure and Economic Growth: An ARDL Approach for the Case of Iran. Journal of Economics and Behavioural Studies. Vol. 3 No. 4, pp, 249-256.

[21]. Bukenya, J., 2009. Do Fluctuations in Health Expenditure Affect Economic Growth? The Open Economics Journal Vol.2 pp,31 -38.

[22]. Ericsson, J. and Irandoust, M., 2001. On the Causality Between Foreign Direct Investment and Output: A Comparative Study, The International Trade Journal, 15(1).

[23]. Aghion, P. and Howitt, P., 1992. A model of Growth Through Creative Destruction. Econometrica, 60(2): pp 323 -51.

[24]. Romer, P., 1990. Endogenous Technological Change. Journal of Political Economy, 98(5), pp, S71-S102.

[25]. Olomola, P. A., 2003. An Economic Analysis of the Determinants of Long-Run Economic Growth In Nigeria. Unpublished P.HD.Thesis.

[26]. Johansen, S., 1991. Estimation and Hypothesis Testing of Co integration Vectors in Gaussian Vector Autoregressive Models. Econometrica, 59(6), pp, 1551-80.

[27]. Johansen, S. and Julius, K., 1990. Maximum Likelihood Estimation and Inference on Co integration with Applications to the Demand for Money. Oxford Bulletin of Economics and Statistics. Vol.52, pp, 169-210.

[28]. Kul, B. L. and Khan, M. 1999, 'A Quantitative Reassessment of the Finance- Growth Nexus; Evidence from a Multivariate VAR'. Journal of Monetary Economics. pp. 3-42

[29]. Soubbotina, T. P. (2004) Beyound Economic Growth; An Introduction to Sustainable Development World Bank Washington D. C.

[30]. Edwards, S., 1989. Openness, Outward-Orientation Trade Liberalization and Economic Performance in Developing Countries. World Bank Working Paper Series, No. 191. 
[31]. Jones, C. I., 1995. R\&D-Based Models of Economic Growth, Journal of Political Economy, 103:4, pp, 759-784.

[32]. Mankiw, N.G., Romer, D. and Weil, D. N., 1992. A Contribution to the Empirics of Economic Growth. Quarterly Journal of Economics, vol.107, pp, 407-437. 